комплексу особистісних i професійних ресурсів, представлених в соціальному компоненті, що забезпечують можливість вирішення професійних завдань у майбутньому, повинно стати основою підготовки майбутніх фахівців сфери послуг.

\title{
Література:
}

1. Гірняк Л.І., Сопіга В.Б. Формування культури та якості обслуговування у готельно-ресторанних підприємствах. Науковий вісник Ужгородського національного університету. 2018. Вип. 21. Ч. 1. C. $50-54$.

2. Дуглас В.П. Бессознательный брендинг. Использование в маркетинге новейших достижений нейробиологии. М.: Азбука, 2014. $320 \mathrm{c}$.

3. Коваль Л.П., Мельник В.В. Соціальна відпоівдальність бізнесу в контексті явищ у виробничій сфері. Економіка і суспільство. 2018. Вип. 19. С. 417-421. URL: http://economyandsociety.in.ua/journal/ 19_ukr/63.pdf

4. Поважний О.С., Орлова Н.С. Формування корпоративної стратегії на основі соціальної відповідальності. Менеджер. 2014. № 1. C. 4-10. URL: http://nbuv.gov.ua/UJRN/Nzhm_2014_1_3

5. Шпичко I.О. Формування соціальної компетентності майбутніх фахівців сфери обслуговування у професійній підготовці: дис. ... канд. пед. наук: 13.00.04. Хмельницький, 2016. 289 с.

DOI https://doi.org/10.30525/978-9934-588-80-8-1.54

\section{ЗНАЧУЩІСТЬ ОСВІТИ У ПІДГОТОВЦІ УСПІШНОЇ ЛЮДИНИ}

\author{
Козьменко О. I. \\ кандидат педагогічних наук, доцент, \\ доиент кафедри іноземних мов та професійної комунікаиії \\ Східноукраїнський національний університет імені Володимира Даля \\ м. Сєвєродонеиьк, Луганська область, Украӥна
}

Успіх відіграє вирішальну роль у житті кожної людини. Прагнення до самореалізації, здійснення мрій, задоволення власних соціальних, духовно-культурних та економічних потреб є притаманним кожній людині. Як відомо, успіх визначається як отримання максимального результату з мінімальними витратами енергії, часу й зусиль, при цьому цей результат має задовольняти внутрішні глибинні потреби людини й 
викликати почуття задоволення, а також схвалення дій 3 боку суспільства [1]. Успіх створює особливий стан відчуття розвитку й особистісного росту, а це передбачає достатню активність людини, пошукову діяльність, цілеспрямованість й використання найраціональніших засобів й методів досягнення мети. «Успішна людина - це та, яка достигла особистісно та встигла соціально. У цьому значенні успішним є той, хто переконує світ в значущості свого життєвого проекту» [3]. Успіх може мати зовнішній (соціальний) або внутрішній (особистісний) прояв. Підготовка успішної людини передбачає формування такої особистості, яка, одночасно, може залишатися вірною власним внутрішнім установкам і цінностям, тобто проявляти внутрішню (екзистенціальну) успішність та бути адаптованою до вимог суспільства (проявляти соціальну успішність). Постає питання формування необхідних компетенції, навичок, які б сприяли цьому процесу. Тому виникає питання яку роль в підготовці успішної людини виконує освіта. Можна зазначити, що «особливості характеру й морально-етичні якості людини, духовні цінності й соціальні норми формують уявлення людини про успіх. Освіта, як соціально-культурна інституція, має за мету не тільки надати необхідні знання, навички й уміння, але робить акцент на процес формування людини, виховання духовно-культурних цінностей, ідей, ставлення до світу та власної особистості. Освіта є середовищем, де відбувається становлення й розвиток особистості, розкриття духовного потенціалу, формування успішної людини. Як вказують науковці, завдяки освіті розкривається людська екзистенція, поза межами якої розвиток людини взагалі, та їі успішності, зокрема, неможливий [3]. Виступаючи у ролі середовища й засобу підготовки успішної людини освіта має унікальні можливості щодо формування індивідуальної траєкторії розвитку індивіда, становлення його ідентичності й вибору власного шляху самореалізації. Якщо середня освіта готує дитину до подальшого успішного навчання, то вища освіта надає базу для життєвого й професійного успіху. Відомо, що система американської вищої освіти є однією з найкращих у світі й досвід підготовки успішної людини в США є корисним для вітчизняної педагогіки. Прагматичне американське суспільство в процесі історичного розвитку сформувало власну ідею успіху, яка передбачає індивідуальні досягнення, які частіше вимірюються на основі матеріальних показників [2]. Тому вища освіта в США перебуває у якості «фабрики з формування» успішної людини, оскільки надає можливість отримати необхідну професію для успішної кар'єри. Але останнім часом, все більше досліджень доводять той факт, що для успіху набагато важливіше мати не суто професійні знання, досвід у 
певній сфері, але набути навичок, які допоможуть самореалізуватися. Уміння спілкуватися 3 людьми, критично й креативно мислити, знаходити вихід у складних ситуаціях, аналізувати інформацію та створювати власні проекти цінуються значно більше ніж професійні уміння [4]. Як вказують американські педагоги, вища освіта - це надзвичайно цінна можливість отримати незабутній досвід. Заклад вищої освіти, як унікальна установа, може бути для студентів багатогранною навчальною лабораторією, наповненою необхідними ресурсами, що надають соціальні, фінансові, академічні та особистісні переваги. Це $\epsilon$ найкращім місцем, де здобувачі вищої освіти можуть навчитися ефективно розвивати різні аспекти своєї особистості за підтримки професійно підготовлених викладачів [6]. Здобуття вищої освіти - це незабутня подорож у світ знань й особистісного розвитку, але, враховуючи той факт, що сучасні студенти стикаються 3 різноманітними життєвими й суспільними проблемами не тільки під час навчання, але й подальшому житті, професійній кар'єрі, визначення успіху потребує розширеного визначення. Таке визначення пропонує Амелія Парнелл (США), вказуючи на значущість під час навчання досягнення чотирьох значних результатів. Автор наголошує, що такі результати потрібні студентам у досягненні успіху, а саме: успішність залежить від уміння пристосуватися до соціального середовища, або, за необхідністю, ще й змінити його під власні потреби; успішність потребує розуміння власних потреб та потреб інших людей заради встановлення пріоритетів суспільних інтересів над власними; уміння здобувати й відповідально використовувати необхідні для навчання ресурси; усвідомлення необхідності застосовувати свій досвід, знання й навички заради покращення окремого суспільства й світу взагалі, сприяє успіху людини [6]. Значущість вищої освіти полягає у вихованні високорозвинених особистостей, гідних громадян, здатних змінити суспільство на краще, зробити посильний внесок у суспільний добробут. У зв'язку з цим, підготовка успішної людини передбачає формування необхідних здібностей, якостей, компетенцій. Форми й методи навчання в американських ЗВО сприяють створенню атмосфери довіри й творчості, де розкривається потенціал людини, студенти стають повноправними учасниками освітнього процесу, мають право вибору навчальних курсів, власного темпу навчання й ступеня навантаження протягом семестру, впливають на зміни в освітніх програмах. Велика конкуренція серед закладів вищої освіти вимагає від них створення умов для ефективного навчання, впровадження нових освітніх технологій, оновлення навчальних планів й розробку стратегій підвищення успішності студентів. Досвід створення різноманітних 
програм підтримки студентів, Центрів успіху, інформаційних матеріалів з метою надання допомоги у навчанні й подальшій кар'єрній реалізації є цікавим й потребує подальшого дослідження. Заохочення студентів до активної співпраці як в аудиторний, так i у поза аудиторний час, на думку, американських освітян, надає додаткову перевагу у вихованні таких якостей, як комунікабельність, відкритість, соціальна активність, сміливість та ін. Формування активної життєвої позиції, власного світогляду, толерантного ставлення до всіх членів суспільства відбувається в процесі спілкування й відкритого обговорення різноманітних актуальних для США тем [5]. У такий спосіб відбувається процес підготовки успішної людини і значущість вищої освіти полягає в тому, що вона слугує осередком, й, одночасно, i засобом реалізації особистісного потенціалу, формування життєвої стратегії, соціального ствердження власних життєвих проектів. Місія освіти - надати здобувачу можливість визначити вектор розвитку своєї особистості, шляхи досягнення успіху, показати ефективні стратегії реалізації життєвого потенціалу.

\section{Література:}

1. Караханян Е.В. Социально-философская концепция успеха. Автореф. дисс. .... канд. филос. наук. - Уфа: 2010. - 19 с.

2. Маркозова О.О. США: держава, побудована на фреймі індивідуального успіху особистості // Вісник Національного університету «Юридична академія України імені Ярослава Мудрого». Серія: Філософія, філософія права, політологія, соціологія. 2015. № 2 (25). URL: https://cyberleninka.ru/article/n/ssha-derzhava-pobudovana-na-freymiindividualnogo-uspihu-osobistosti (дата звернення: 23.09.2020).

3. Степанова С. Н. Образование в ракурсе философии успеха // Известия ТПУ. 2012. № 6. URL: https://cyberleninka.ru/article/n/ obrazovanie-v-rakurse-filosofii-uspeha (дата звернення: 23.09.2020)

4. Anders, G. (2017). You can do anything: the surprising power of a «useless» liberal arts education. First edition. New York: Little, Brown and Company

5. Davidson, C. N. (2017). The New Education: How to Revolutionize the University to Prepare Students for a World in Flux. New York: Basic Books

6. Parnell, A. (2018, Aug.23). It's Time for a Real Definition of Student Success. Retrieved from: https://higherlearningadvocates.org/2018/08/23/ its-time-for-a-real-definition-of-student-success/ 